\title{
Phenological behavior of Atlas cedar (Cedrus atlantica) forest to snow and precipitation variability in Boutaleb and Babors Mountains, Algeria
}

\author{
KHALED MISSAOUI ${ }^{1,2, \boldsymbol{v}}$, RACHID GHARZOULI $^{1,2}$, YAMNA DJELLOULI $^{3}$, FRANÇOIS MESSNER $^{3}$ \\ ${ }^{1}$ Laboratory Urban Project, City and Territory, Faculty Architecture and Earth Sciences, University of Ferhat Abbas Setif 1. El Bez, Sétif 19000, Algeria. \\ "email:missaouikhaled90@yahoo.com \\ ${ }^{2}$ Departmnent of Plant Biology and Ecology, Faculty of Nature and Life Sciences, University of Ferhat Abbas Setif 1, El Bez, Sétif 19000, Algeria \\ ${ }^{3}$ Laboratory Geographical Spaces and Societies (ESO- UMR6590 CNRS), University of Maine. Avenue Olivier Messiaen, 72085 Le Mans, France
}

Manuscript received: 5 November 2019. Revision accepted: 24 December 2019.

\begin{abstract}
Missaoui K, Gharzouli R, Djellouli Y, Messner F. 2020. Phenological behavior of Atlas cedar (Cedrus atlantica) forest to snow and precipitation variability in Boutaleb and Babors Mountains, Algeria. Biodiversitas 21: 239-245. Understanding the changes in snow and precipitation variability and how forest vegetation response to such changes is very important to maintain the long-term sustainability of the forest. However, relatively few studies have investigated this phenomenon in Algeria. This study was aimed to find out the response of Atlas cedar (Cedrus atlantica (Endl.) G.Manetti ex Carrière) forest in two areas (i.e Boutaleb and Babors Mountains) and their response to the precipitation and snow variability. The normalized difference vegetation index (NDVI) generated from satellite images of MODIS time series was used to survey the changes of the Atlas cedar throughout the study area well as dataset of monthly precipitation and snow of the province of Setif (northeast of Algeria) from 2000 to 2018. Descriptive analysis using Standarized Precipitation Index (SPI) showed the wetter years were more frequent in the past than in the last two decades. The NDVI values changes in both areas with high values were detected in Babors Mountains with statistically significant differences. Our findings showed important difference in Atlas cedar phenology from Boutaleb mountains to Babors Mountains which likely related to snow factor.
\end{abstract}

Keywords: Atlas cedar, forest, NDVI, precipitation, snow

\section{INTRODUCTION}

During the last century, climate change has had a great influence on the natural ecosystem. For this reason, research about climate change is becoming very important and more and more studies have been carrying out $(\mathrm{Li}$ 2009). That's why the international community brought great interest to climate scientists leading to several studies on climate trend detection at various scales in which these trends have resulted in, warmer temperatures and changed precipitation regimes (Chmura et al. 2011). Consequently, one of the expected impacts due to these dynamics is the changes in the distribution of plant species (Demarteau et al. 2007).

Studies related to climate variability and plant responses to it are still rare in Algeria. Most forests of the world are suffering a decrease in extent. This degradation is due to many factors including climate change, increasing human population, wildfires and water scarcity. Climate change remains the most significant threat to all Mediterranean forests. Rising temperatures, erratic rain patterns, and longer droughts will significantly alter the vegetation cover and distribution of forests and trees over the next years.

As trees try to withstand droughts, they deplete their carbon stocks and produce fewer carbohydrates and resins, which are essential to their health. This has already led to a decline or dieback of oak and Atlas cedar trees in Algeria. Cedrus atlantica (Endl.) Manetti ex Carrière is a montane conifer found in semi-arid and humid areas of Morocco and
Algeria, typically occurring on exposed north and northwestern slopes of the Rif and Atlas (Middle, High, and Algerian Tell) mountain ranges at an elevation of 1400-2600 m above sea level (Benabid, 1982; Farjon, 1990). It is cold tolerant and drought resistant, but sensitive to extreme or prolonged drought stress (Aussenac, 1984; Cheddadi et al. 2009; Linares et al. 2011, 2013; Rhanem 2011; Ilmen et al. 2014). During recent decades, high rates of mortality of Cedrus atlantica have been reported in Algeria (Bentouati 2008; Alileche 2012; Megdoud 2012; Kherchouche et al. 2013). Recent studies (Cheddadi et al. 2009; Allen et al. 2010; Slimani et al. 2014) reported that recent tree growth was mainly influenced by precipitation variability.

The forest ecosystems in the province of Setif which located in the North East of Algeria have attracted the attention of several researchers (e.g. Gharzouli 2007; Bounar 2014), because of the enormous value it provides for the local population in their everyday needs (e.g. wood, timber, food, etc.), as well as for local authorities and urban communities. Among these forests, Boutaleb and Babor forests have been gaining popularity as a tourist attraction, due to its rich biodiversity and ecosystem values. It is dominated by the Atlas cedar (Cedrus atlantica) known as a noble tree species.

In this case, to gain a more comprehensive understanding of how this species response to precipitation variability, remote sensing techniques have been recognized as a powerful means to obtain information on Earth's surface features (Satyanarayana et al. 2001) at 
different spatial and temporal scales (Liang et al. 2015). In this paper, we applied a sensitivity analysis of datasets of monthly precipitation and snow of the province of Setif (north east of Algeria) from 2000 to 2018. The normalized difference vegetation index (NDVI) was used to survey the changes of the Atlas cedar throughout the study area. The main objective of this study was to find out the difference between the Atlas cedar of two forests (Boutaleb and Babor) and their relationship to the precipitation and snow variability.

\section{MATERIALS AND METHODS}

\section{Study area}

The study area was located in the north-east part of Algeria in the province of Setif. The Atlas cedar forest was located in Boutaleb mountains and Babor mountains which culminate at $1864 \mathrm{~m}$ and $2004 \mathrm{~m}$ respectively (Figure 1).

The study area was an open forest consisting of almost pure stands of Atlas cedar with minor occurrence of Quercus ilex.

Table 1. Geographic, ecological, and climate information of the two sampling site

\begin{tabular}{lll}
\hline \multicolumn{1}{c}{ Description } & $\begin{array}{c}\text { Site I } \\
\text { (Boutaleb Mountains) }\end{array}$ & $\begin{array}{c}\text { Site II } \\
\text { (Babor Mountains) }\end{array}$ \\
\hline Latitude (N) & $35^{\circ} 44^{\prime} 6 "$ " N & $36^{\circ} 30^{\prime} 7.2^{\prime \prime} \mathrm{N}$ \\
Longitude (E) & $5^{\circ} 21^{\prime} 14.4^{\prime \prime} \mathrm{E}$ & $5^{\circ} 28^{\prime} 26.4^{\prime \prime} \mathrm{E}$ \\
Elevation (m) & 1500 & 1500 \\
Aspect & North & Northeastt \\
Trees & Cedrus atlantica & Cedrus atlantica \\
Q2 (Emberger & 40 & 168 \\
quotient) & & \\
\hline
\end{tabular}

\section{Data collection}

For investigation of the Atlas cedar forest, we selected one area in every site with an extent of $900 \mathrm{~m}^{2}$ during the period between 2015 and 2018. Every point contains type of formation, geographic situation and altitude using Global Positioning System (GPS).

\section{Data sources}

The data in the present study including measurements of mean temperature, precipitation and snow were obtained from the State Meteorological Service in Algeria from 1982 to 2017. We used satellite images dates from $18 / 02 / 2000$ to $25 / 05 / 2018$ of MODIS. As many as 420 scenes covering the study area were obtained in this period to survey the natural vegetation in the study area and to analyze the relationships between forest and climate variability.

\section{Data analysis}

Precipitation and snow analysis

Descriptive statistics were used with XLSTAT 2019.1.2 software for data and time series analysis. Monthly total precipitation and the number of days of snow from the weather station of Setif were used.

The Standardized Precipitation Index (SPI) (McKee et al. 1993; Svoboda 1999; Svoboda et al. 2012) is widely used to detect precipitation deficit-drought—or precipitation excess-wetter periods. The SPI is computed as:

$$
\mathrm{SPI}=\sum_{j}^{N i} \frac{P_{j}^{i}-\overline{P_{j}}}{\sigma_{j}}
$$

Where Pij is the rainfall of year $\mathrm{i}$ at station $\mathrm{j}, \mathrm{Pj}$ is the interannual mean rainfall at station $\mathrm{j}, \sigma \mathrm{j}$ is the standard deviation of the annual rainfall series at station $\mathrm{j}$, and $\mathrm{Ni}$ is the number of stations of year $i$.
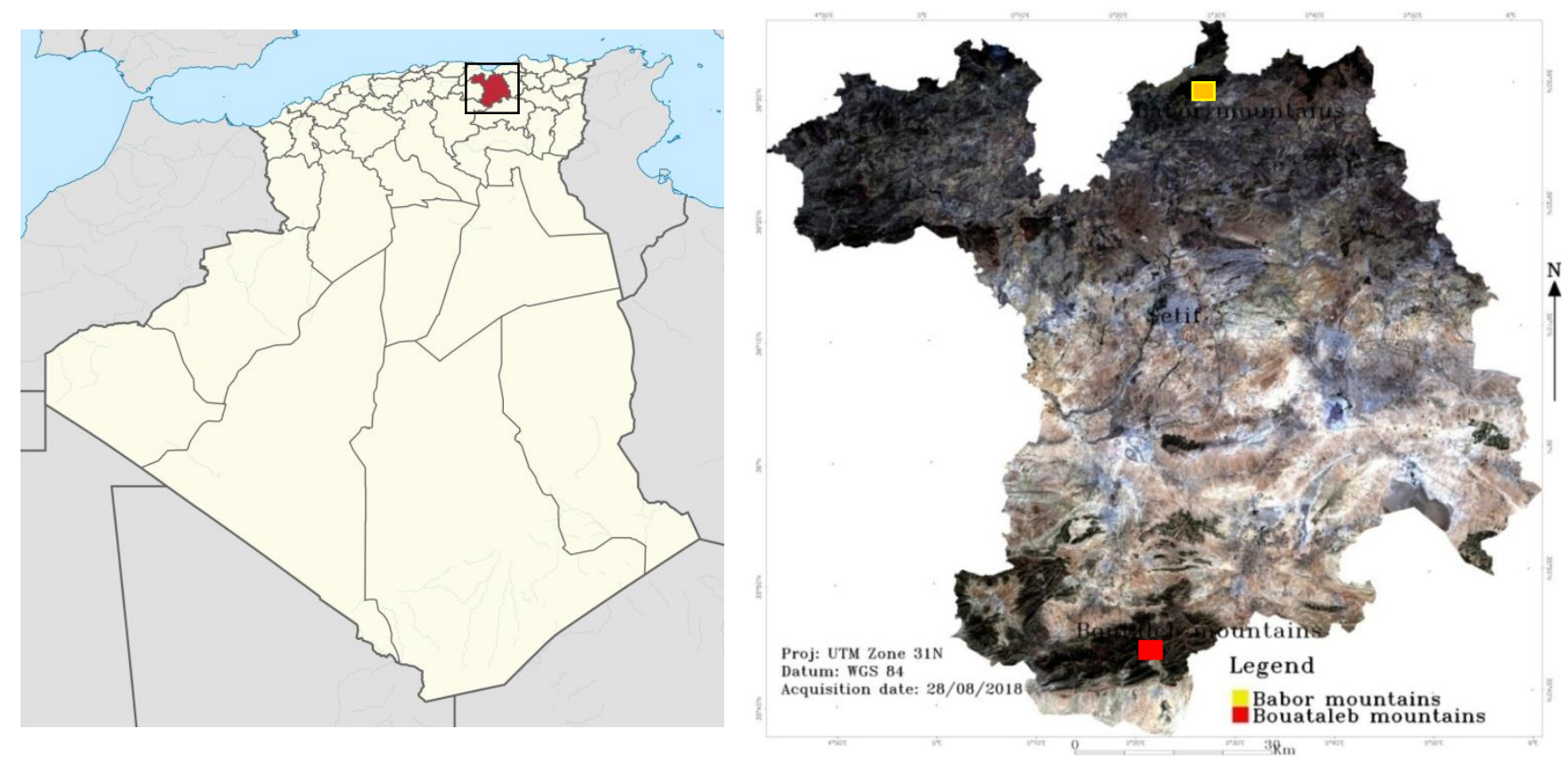

Figure 1. The map of study area (in Boutaleb and Babors Mountains, Setif Province, Algeria) over natural color composition obtained from Landsat 8 satellite processed with ENVI 5.1 software 
The SPI values (Table 2) can be interpreted as the number of standard deviations by which the observed anomaly deviates from the long-term mean.

The SPI value is the number of standard deviations by which the observed anomaly deviates from the long-term mean. SPI values from -2.0 and less to -1.0 identify dry periods, from -0.99 to 0.99 identify near-normal periods and from 1.0 to $2.0+$ identify wet periods (Velia et al. 2018).

Table 2. The Standardized Precipitation Index (SPI) used in this study

\begin{tabular}{ll}
\hline & SPI Values \\
\hline $2.0+$ & Extremely wet \\
1.5 to 1.99 & Very wet \\
1.0 to 1.49 & Moderately wet \\
-0.99 to 0.99 & Near normal \\
-1.0 to -1.49 & Moderately dry \\
-1.5 to -1.99 & Very dry \\
-2.0 and less & Extremely dry \\
\hline
\end{tabular}

\section{Change in phenology of Atlas cedar forest}

The Normalized Difference Vegetation Index (NDVI) was used as a proxy for vegetation density in the two sites (the Mountains of Babor and Boutaleb) associated with the intensity of photosynthetic activity (Wang et al. 2004). It was measured using the red band and near-infrared band from satellite image using the classic formula:

\section{$\mathrm{NDVI}=\mathrm{IR}-\mathrm{R} / \mathrm{IR}+\mathrm{R}$} band.

Where: IR and $\mathrm{R}$ are respectively the infrared and red

\section{Statistical analyses}

Using the NDVI and snow data in period of 2000-2017, we examined the relationship between number of the day of snow and NDVI using linear regression to determine a best-fit regression line for each study area. We determined the 95 percent confidence intervals, the $95 \%$ prediction interval, the R2, F-statistic, and p-value for the linear regression. We then compared NDVI values of the two sites. We tested this hypothesis with a single-sample t-test. This test shows whether the NDVI of Atlas cedar of
Boutaleb is statistically significantly different from the NDVI of Atlas cedar of Babor.

\section{RESULTS AND DISCUSSION}

\section{Precipitation and snow variability}

Precipitation is one of the most important resources of water in forest ecosystem. This variable is useful to investigate climate change impacts on forest ecosystems (Beldjazia and Alatou 2016). In order to assess precipitation variability, descriptive statistics were used. Results in Table 3 show that the maximum value of precipitation was observed in December. The highest mean precipitation value was recorded in May, indicating that precipitation is very important in the spring season. The coefficient of variation values was very high across all months, and reached a very high value for the summer season, suggesting the intensity of the variability of precipitation during this season. So we can say that the dispersion around the mean is large and that the data are heterogeneous.

In order to help understanding precipitation variability, The Standardized Precipitation Index was used. Figure 2 shows the changes in SPI from the period of 1982 to 2017. We found that the year 2003 was extremely wet and the year 1983 was extremely dry. The results found by Beldjazia and Alatou (2016) on the massif forest of Mahouna (Algeria) indicated that the year 2003 had a very wet winter.

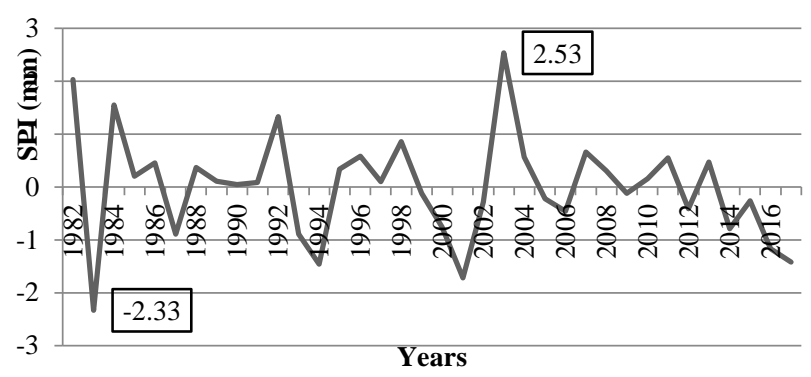

Figure 2. Standardized Precipitation Index (SPI) from the period of 1982 to 2017

Table 3. Descriptive statistics of the precipitation data from the period 1982 to 2017

\begin{tabular}{lllllllllllll}
\hline Statistic & Jan & Feb & Mar & Apr & Mai & Jun & Jul & Aug & Sep & Oct & Nov & Dec \\
\hline Nb. Of observations & 36 & 36 & 36 & 36 & 36 & 36 & 36 & 36 & 36 & 36 & 36 & 36 \\
Min value [mm] & 5.600 & 2.100 & 0.000 & 2.200 & 2.700 & 0.000 & 0.000 & 0.000 & 0.000 & 0.800 & 5.600 & 0.000 \\
Max value [mm] & 130.700 & 105.400 & 102.000 & 89.200 & 101.500 & 72.700 & 44.300 & 35.300 & 120.000 & 103.800 & 100.100 & 133.000 \\
Median & 34.800 & 33.750 & 30.500 & 41.150 & 46.900 & 20.000 & 8.400 & 12.900 & 31.150 & 26.250 & 29.650 & 34.750 \\
Mean value [mm] & 42.169 & 36.067 & 35.733 & 41.514 & 44.347 & 21.500 & 10.617 & 14.261 & 36.675 & 32.000 & 36.231 & 43.086 \\
Variance & 848.446 & 587.357 & 555.277 & 635.787 & 796.188 & 331.833 & 149.954 & 123.265 & 770.303 & 559.008 & 485.883 & 924.264 \\
Ecart-type & 29.128 & 24.235 & 23.564 & 25.215 & 28.217 & 18.216 & 12.246 & 11.102 & 27.754 & 23.643 & 22.043 & 30.402 \\
Coefficient of variation & 0.691 & 0.672 & 0.659 & 0.607 & 0.636 & 0.847 & 1.153 & 0.779 & 0.757 & 0.739 & 0.608 & 0.706 \\
\hline
\end{tabular}


Table 4. Descriptives statistics of Standardized Precipitation Index (SPI)

\begin{tabular}{lcccc}
\hline Lower bound & Upper bound & Effective & Freq. & Density \\
\hline-3 & -2.5 & 0 & 0.000 & 0.000 \\
-2.5 & -2 & 1 & 0.028 & 0.056 \\
-2 & -1.5 & 1 & 0.028 & 0.056 \\
-1.5 & -1 & 3 & 0.083 & 0.167 \\
-1 & -0.5 & 4 & 0.111 & 0.222 \\
-0.5 & 0 & 7 & 0.194 & 0.389 \\
0 & 0.5 & 11 & 0.306 & 0.611 \\
0.5 & 1 & 5 & 0.139 & 0.278 \\
1 & 1.5 & 1 & 0.028 & 0.056 \\
1.5 & 2 & 1 & 0.028 & 0.056 \\
2 & 2.5 & 1 & 0.028 & 0.056 \\
2.5 & 3 & 1 & 0.028 & 0.056 \\
\hline
\end{tabular}

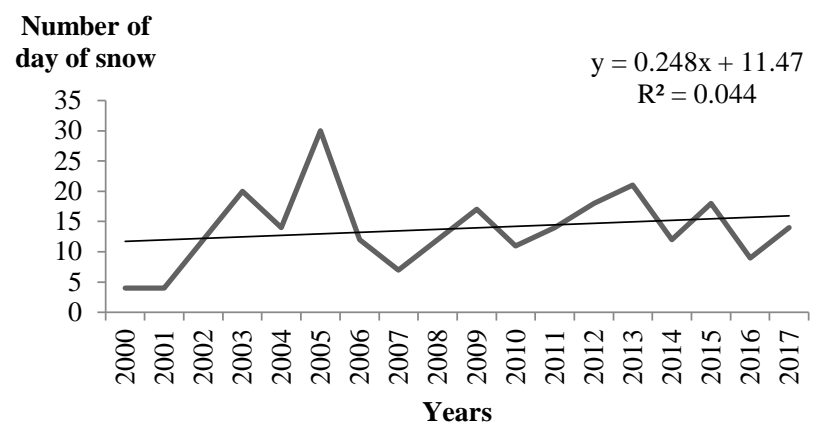

Figure 3. Number of day of snow from the period of 2000 to 2017

Descriptive statistics on SPI data were used to detect precipitation deficit or excess during this period (Table 3). Compared to Figure 2, which clearly explains the category of SPI values to wet, normal and dry periods, it was more common to have wetter years in the past than in the last two decades where, at the contrary, especially in the first part, extremely negative SPI's values were more frequent as the effect of drought.

In mountain environments, particularly in winter, most precipitation falls as snow, with elevation and temperature as determining factors (Smithson et al. 2008). The snow season usually starts in November and finishes in April.

The effects of snow on soil and vegetation are in majority positive. By melting, snow feeds runoffs and grounds with freshwater, nourishing thereby plants and contributing to nutrient fluxes and cycling (Tranter and Jones 2001; Wang et al. 2015).

As for snow cover, the pattern was still not clear due to the absence of weather station in the mountains of the study area. From the data obtained from the OMS weather of Setif, we found that the number of the day of snowing varied from year to year, and there has been not significant change over the last two decades $\left(\mathrm{R}^{2}=0.044\right)$ (Figure 3 ). Recent studies did not report either any substantial change in snow cover dynamics. Research by Legdou (2008) in Ifrane for the period of 1958-2006 found a marginally significant decrease in snow depth, while Marchane et al. (2015) did not detect any significant long-term change between 2000 and 2013.

\section{Change in phenology of Atlas cedar forest}

Vegetation growth can be measured with different spectral-based Vegetation Indices (VIs), such as the Enhanced Vegetation Index (EVI) and the Normalised Difference Vegetation Index (NDVI) (Tan et al. 2008; Trujillo et al. 2012; Paudel and Andersen 2013; Wang et al. 2015). A Vegetation Index is an indicator of the density of green leaves (Weier and Herring 2000). Used primarily for vegetation mapping and monitoring, vegetation index can act as proxy measures of vegetation productivity, photosynthetic activity and phenology metrics (e.g. Leaf Area Index (LAI) and biomass spatio-temporal variations, etc.) (Huete et al. 1997; Weier and Herring 2000).

Figure 4 shows the comparison between the NDVI of Atlas cedar in the Babor and Boutaleb mountains computed from MODIS images. The NDVI values changed for every area with high values in Babor Mountains. The Atlas cedar in Boutaleb Mountains changes in the same range while we note the irregularity in Babor Mountains. This was marked by the highest and the lowest values in every year from the study period.
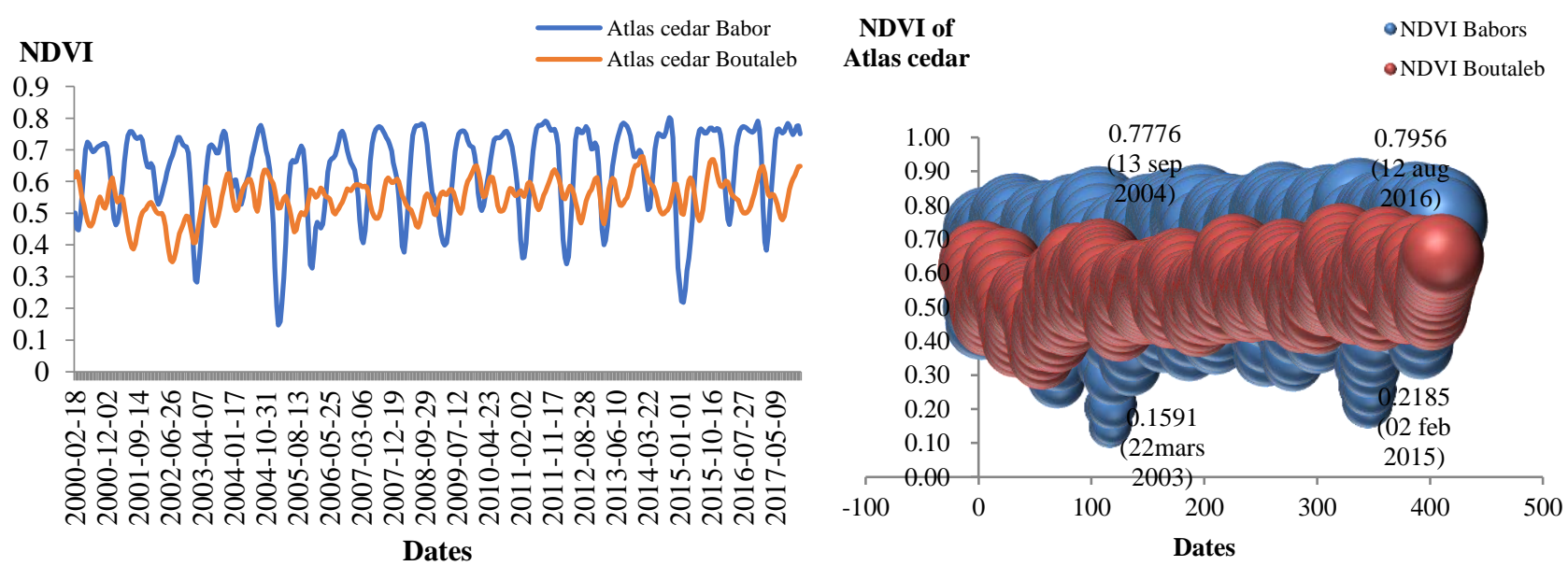

Figure 4. Diachronic variations of NDVI in Atlas cedar of Babor and Boutaleb Mountains, Algeria from the period of 2000 to 2017 
Table 5. The results of Student's t-test showing significant differences of remotely sensed NDVI between Atlas cedar of Babor and Boutaleb Mountains, Algeria

\begin{tabular}{ll}
\hline Difference & $\mathbf{0 . 0 8 8}$ \\
\hline $\mathrm{t}$ (Observed value) & 6.619 \\
$|\mathrm{t}|$ (Critical value) & 2.032 \\
DDL & 34 \\
p-value (bilateral & $<0.0001$ \\
alpha & 0.05 \\
\hline
\end{tabular}

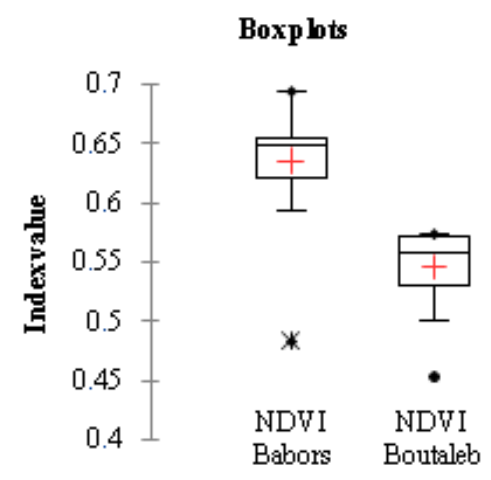

Figure 6. Boxplot of NDVI of Atlas cedar forest of Babor and Boutaleb Mountains, Algeria derived from MODIS images in the period 2000 to 2017.

Table 6. Linear regression of NDVI variables

\begin{tabular}{lcc}
\hline & NDVI Babor & NDVI Boutaleb \\
\hline $\mathrm{R}^{2}$ & $\mathbf{0 . 5 3 1}$ & 0.006 \\
$\mathrm{~F}$ & 18.106 & 0.102 \\
$\mathrm{Pr}>\mathrm{F}$ & 0.001 & 0.753 \\
\hline
\end{tabular}

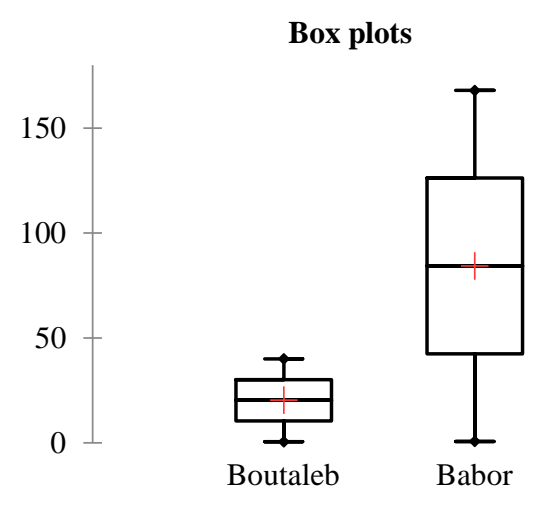

Figure 7. Box plot of linear regression of NDVI variables of Boutaleb and Babors Mountains, Algeria

Our results were statistically analyzed using student's ttest to compare the phenology changes between two sites. As shown in Table 4, significant differences were found in the NDVI values between Boutaleb and Babors Mountains $(\mathrm{p}<0.0001)$. The Atlas cedar of Babor can be clearly distinguished with the high box plot beside the Boutaleb box plot (Figure 5).

To better explain the difference between the two mountains, we used linear regression analysis at 5\% significance level of NDVI values. Results performed over the series for total number of day of snow, given the $\mathrm{p}$ value associated with the $\mathrm{F}$ statistic calculated in the variance analysis (Table 6). The information provided by the explanatory variables of NDVI of Babor was significantly better compared to the snow variable $\left(\mathrm{r}^{2}=\right.$ $53 \%)$.

Satellite images generated from MODIS can be useful in detecting, measuring, mapping and monitoring vegetation growth in a topographically complex area, as we have in Boutaleb and Babors Mountains. Similar analyses had been conducted to investigate the phenological patterns of alpine larch forests and grasslands in the Aosta Valley of northwestern Italy by Busetto et al. (2010) and Colombo et al. (2009, 2011) using MODIS time series for different periods between 2000 to 2009 in relation to climatic factors and elevation.

Our findings throughout the variation of NDVI derived from MODIS image showed very important values during the winter season which was explained to the role of precipitation and snow. Several other studies based on plant phenology measures showed that vegetation growth could be approximated with snow presence, notably in the Alps, another Mediterranean mountain system, showed that snowpacks may outweigh the favorable effects (Wipf et al. 2010; Choler 2015). A study by Choler (2015) also presented grassland phenology in the French Alps in response to snow cover. Enriching those studies regarding the response of vegetation to snow, our findings allow us to better understand these phenomena in the phenology of Atlas cedar forest.

In general, we can say that the use of remote sensing provides rapid information on detecting the change in development and/or decrease in the forests their surface over time and over relatively large areas. In Algeria, few studies had been done to reveal the dynamics of Atlas cedar forest during last two decades such as research of Belloula and Beghami (2018) for the Chelia Mountains, where they found the large percentage of decrease of Atlas cedar observed in the period 1999-2016 for the Ouled Yagoub Mountain. The study concluded that this change is likely a consequence of climate change (Belloula and Beghami 2018).

Our results are in agreement with those found by Ilman et al. (2014) in the related climate change in which Atlas cedar in a forest site named "Taoalt" located in the Eastern Middle Atlas of Morocco showed a positive growth response to precipitation. The rainfall was very important in the growth of such forests (Ilman et al. 2014). In other studies, Allen et al. (2010) showed that forest mortality related to events that were driven by climatic water/heat stress since 1970. Also, Linares et al. (2011) reported an increase in drought events and temperature since the 1970s, and noticed consistent decline and increased drought sensitivity in $C$. atlantica stands since the early 1980 s. 
During winter, precipitation in the mid-elevations and upward falls in the form of snow rather than rain. The increase observed may be explained by a greater dependence on snowpacks as a source of water, in addition to enhanced soil conditions. These phenomena are explained by the distribution of the box plot of linear regression of NDVI variables found in Boutaleb and Babors Mountains.

In conclusion, this is the first phenology study of the response of vegetation to climate variability using Atlas cedar forest in North Africa, specifically in Algeria. Atlas cedar trees are natural archives of past events. We found during the last two decades, NDVI frequency of the Atlas cedar forests declined dramatically. Climatic factors in terms of precipitation and snow have played a major role in the changes of Atlas cedar forest in the study area. The climatic analyzes in forest ecosystems of the province of Setif (northeast of Algeria) indicated that there have been wetter years in the past than in the last two decades. Our findings showed important difference in Atlas cedar phenology from Boutaleb mountains to Babor mountains which likely related to snow factor.

\section{ACKNOWLEDGEMENTS}

The authors would like to thank the direction of Forest Conservation of the province of Setif, Ain el Kbira and Ain Oulmene (Algeria) for providing all research facilities in the site of Boutaleb and Babors Mountains (north-east of Algeria).

\section{REFERENCES}

Allen CD, Macalady AK, Chenchouni H, Bachelet D, McDowell N, Vennetier M, et al. 2010. A global overview of drought and heatinduced tree mortality reveals emerging climate change risks for forests. For Ecol Manag 259: 660-684.

Alexander L, Perkins S. 2013. Debate heating up over changes in climate variability. Environ Res Lett 8: 041001,

Beldjazia A, Alatou D. 2016. Precipitation variability on the massif Forest of Mahouna (North Eastern-Algeria) from 1986 to 2010. Intl J Manag Sci Buss Res 5 (3): 21-28.

Belloula S, Beghami Y.2018. Assessment of the dynamic of Atlas Cedar Decline(Cedrus atlantica Manetti) by Remote sensing in the Aurès area, Algeria. The Arab World Geographer / Le Géographe du monde arabe 21 (2-3): 154-167.

Velia B, Alessandro P, Rosso M. 2018. Past and future precipitation trend analysis for the City of Niamey (Niger): An overview. Climate 6: 73; DOI: $10.3390 /$ cli6030073.

Bounar R. 2014. Study of biological potentialities mapping and development of the chain of Babors in the sustainable development approach. [Dissertation]. Setif Univ., Algeria. [France]

Brohan P, Kennedy JJ, Harris I, Tett SFB, Jones PD. 2006. Uncertainty Estimates in Regional and Global Observed Temperature Changes: A New Dataset from 1850," J Geophys Res 111: D12106. DOI: 10.1029/2005JD006548

Busetto L, Colombo R, Migliavacca M, Cremonese E, Meroni M, Galvagno M, Rossini M. Siniscalco C. Morra di Cella U, Pari E. 2010. Remote sensing of larch phenological cycle and analysis of relationships with climate in the Alpine region. Glob Chang Biol 2010: 2504-2517.

Choler P. 2015. Growth response of temperate mountain grasslands to inter-annual variations in snow cover duration. Biogeosciences 2015, 12: 3885-3897.
Colombo R, Busetto L, Fava F, Di Mauro B, Migliavacca, M, Cremonese, E, Galvagno M, Rossini M, Meroni M, Cogliati S, et al. 2011. Phenological monitoring of grassland and larch in the Alps from Terra andAqua MODIS images. Rivista Italiana di Telerilevamento 43: 83-86.

Colombo R, Busetto L, Migliavacca, M, Cremonese E, Meroni, M, Galvagno, M, Rossini M, Siniscalco C, Morra di Cella U. 2009. On the spatial and temporal variability of Larch phenological cyclein mountainous areas. Rivista Italiana di Telerilevamento 41: 79-96.

Coumou D, Robinson A. 2013. Historic and future increases in the global land area affected by monthly heat extremes. Environ Res Lett 8: 034018, DOI: 10.1088/1748-9326/8/3/034018.

Gharzouli R. 2007. Flora and vegetation of Kabylie Babors: Floristic and phytosociological study of forest and post-forest groups of Takoucht, Adrar Or-Mellal, Tababort and Babor Djebels. [Dissertation]. Setif Univ., Algeria.

Guttman NB. 1999. Accepting the standardized precipitation index: A calculation algorithm. J Am Water Resour Assoc 35: 311-322.

Hansen J, Sato M, Ruedy R. 2012. Perception of climate change. Proc Natl Acad Sci USA 109: E2415-E2423,

Huete A, Liu H. Q, Batchily K, Van Leeuwen W. 1997. A comparison of vegetation indices over a global set of TM images for EOS-MODIS. Rem Sens Environ 59: 440-451.

Ilmen R, Sabir A, Benzyane M, Karrouk M.S. 2014. Variability and dynamic response of the cedar to climate change in the Eastern Middle Atlas Mountains, Morocco. Mor J Chem 2 (5): 512516.

Jone PD, Moberg A. 2003. Hemispheric and LargeScale Surface Air Temperature Variations: An Extensive Revision and Update to 2001. J Climate 16: 206-223. DOI: 10.1175/15200442(2003)016<0206:HALSSA>2.0.CO;2

Jones PD, Parker DE, Osborn TJ, Briffa KR. 2011. Global and Hemispheric Temperature Anomalies-Land and Marine Instrumental Records. In: Trends: A Compendium of Data on Global Change. Carbon Dioxide Information Analysis Center, Oak Ridge National Laboratory, U.S. Department of Energy, Oak Ridge, TN, USA. DOI: 10.3334/CDIAC/cli.002

Landscheidt T. 2000. Solar Wind near Earth: Indicator of Variations in Global Temperature, Proceedings of the 1st Solar and Space Weather Euroconference on the Solar Cycle and Terrestrial Climate, Tenerife, Spain.

Liang D, Zuo Y, Huang L, Zhao J, Teng L, Yang F. 2015. Evaluation of the consistency of MODIS land cover product (MCD12Q1) based on Chinese $30 \mathrm{~m}$ globeland 30 datasets: A case study in Anhui Province, China. ISPRS Int J Geo-Inf 4: 2519-2541.

Li X. 2009. Applying GLM Model and ARIMA Model to the Analysis of Monthly Temperature of Stockholm. D-level Essay in Statistics in Spring 2009. Department of Economics and Society, Dalarna University, Sweden.

Linares JC, Taïqui L, Camarero JL. 2011. Increasing Drought Sensitivity and Decline of Atlas Cedar (Cedrus atlantica) in the Moroccan Middle Atlas Forests. Forests 2(3): 777-796.

McKee TB, Doesken NJ, Kleist J. 1993. The relationship of drought frequency and duration to time scale. In: Proceedings of the Eighth Conference on Applied Climatology, Anaheim, CA, USA, 17-22 January; American Meteorological Society: Boston, MA, USA.

Olusegun CF, Rabiu AB, Ndeda JOH, Okogbue EC. 2014. Trends of temperature and signature of solar activity in selected stations in Nigeria. Atmospher Clim Sci 4: 171-178

Paudel KP, Andersen P. 2013. Response of rangeland vegetation to snow cover dynamics in Nepal Trans Himalaya. Clim Ch 117: 149-162. DOI: $10.1007 / \mathrm{s} 10584-012-0562-\mathrm{x}$

Rhines A, Huybers P. 2013. Frequent summer temperature extremes reflect changes in the mean, not the variance. Proc Natl Acad Sci USA 110: E546

Satyanarayana B, Thierry B, Seen DL, Raman A.V, Muthusankar G. 2001. Remote sensing in mangrove research-relationship between vegetation indices and dendrometric parameters: A case for Coringa, east coast of India. In proceeding of the 22nd Asian Conference on Remote Sensing, Singapore, 5-9 November 2001.

Simmons AJ, Berrisford PDP, Hersbach H, Hirahara S, Thépaut JN. 2017. A reassessment of temperature variations and trends from global reanalyses and monthly surface climatological datasets. Quart J Roy Meteor Soc 143, 101-119. 
Simolo C, Brunetti M, Maugeri M, Nanni T, Speranza A. 2010 Understanding climate change-induced variations in daily temperature distributions over Italy. J Geophys Res 115, D22110.

Soon W, Baliunas S, Posmentier ES, Okeke P. 2000 Variations of Solar Coronal Hole Area and Terrestrial Lower Tropospheric Air Temperature from 1979 to Mid-1998: Astronomical Forcing of Change in Earth's Climate," New Astron 4 (8): 563-579. DOI: 10.1016/S1384-1076(00)00002-6

Svoboda M, Hayes M, Wood D. 2012 Standardized Precipitation Index User Guide; World Meteorological Organization, Geneva, Switzerland

Tan B, Morisette JT, Wolfe RE, Gao F, Ederer G, Nightingale J, Pedelty JA. 2008Vegetation phenology metrics derived from temporally smoothed and gap-filled MODIS data. International Geoscience and Remote Sensing Symposium (IGARSS) 3: 593-596. DOI: 10.1109/IGARSS.2008.4779417.
Trujillo E, Molotch NP, Goulden ML, Kelly AE, Bales RC. 2012. Elevation-dependent influence of snow accumulation on forest greening. Nature Geoscience 5: 705-709. DOI: 10.1038/ngeo1571

Wang K, Zhang L, Qiu Y, Ji L, Tian F, Wang C, Wang Z. 2015. Snow effects on alpine vegetation in the Qinghai-Tibetan Plateau. Intl J Digital Earth 8: 58-75. DOI: 10.1080/17538947.2013.848946.x

Wang Y, Woodcock C. E, Buermann W, Stenberg P, Voipio P, Smolander H, Myneni R. B. 2004. Evaluation of MODIS LAI algorithm at a coniferous forest site in Finland. Rem Sens Environ 91: 114-127.

Weier J, Herring D. 2000. Measuring Vegetation (NDVI \& EVI). Earth Observatory. National Aeronautics and Space Administration (NASA), USA. http://earthobservatory.nasa.gov/Features/MeasuringVegetation/meas uring_vegetation_1.php [July 30, 2015].

Wipf S, Rixen C. 2010. A review of snow manipulation experiments in Arctic and alpine tundra ecosystems. Polar Res 29: 95-109. DOI: 10.1111/j.1751-8369.2010.00153.x. 